\title{
Diel population dynamics and mortality of Prochlorococcus in the North Pacific Subtropical Gyre
}

\author{
(D) Stephen J. Beckett ${ }^{1,2, \dagger, *}$, (D) David Demory ${ }^{1,2, \dagger, *}$, (D) Ashley R. Coenen ${ }^{2,3}$, \\ (D) John R. Casey ${ }^{4,5,6}$, (D) Mathilde Dugenne ${ }^{4,5}$, (D) Christopher L. Follett ${ }^{6,7}$, \\ Paige Connell ${ }^{8,9}$, (D) Michael C.G. Carlson ${ }^{10}$, (D) Sarah K. Hu ${ }^{8,11}$, (D) Samuel T. Wilson ${ }^{4,5}$, \\ (D) Daniel Muratore ${ }^{1,2,12}$, (D) Rogelio A. Rodriguez-Gonzalez ${ }^{1,2,12}$, Shengyun Peng ${ }^{1,2,13}$, \\ (D) Kevin W. Becker ${ }^{11,14}$, (D) Daniel R. Mende ${ }^{4,5,15}$, (D) E. Virginia Armbrust ${ }^{16}$, \\ (D) David A. Caron ${ }^{8}$, (D) Debbie Lindell ${ }^{10}$, (D) Michael J. Follows ${ }^{6}$, \\ Angelicque E. White ${ }^{4,5}$, (iD François Ribalet ${ }^{16}$, and (D) Joshua S. Weitz ${ }^{1,2,3,{ }^{*}}$ \\ ${ }^{1}$ School of Biological Sciences, Georgia Institute of Technology, Atlanta, GA, USA \\ ${ }^{2}$ Center for Microbial Dynamics and Infection, Georgia Institute of Technology, Atlanta, GA, USA \\ ${ }^{3}$ School of Physics, Georgia Institute of Technology, Atlanta, GA, USA \\ ${ }^{4}$ Daniel K. Inouye Center for Microbial Oceanography: Research and Education, University of Hawai'i at \\ Mānoa, Honolulu, Hawai'i, HI, USA \\ ${ }^{5}$ Department of Oceanography, University of Hawai'i at Mānoa, Honolulu, Hawai'i, HI, USA \\ ${ }^{6}$ Department of Earth, Atmospheric, and Planetary Sciences, Massachusetts Institute of Technology, Boston, \\ MA, USA \\ ${ }^{7}$ Cardiff University, Wales, UK \\ ${ }^{8}$ Department of Biological Sciences, University of Southern California, Los Angeles, CA, USA \\ ${ }^{9}$ Biology Department, San Diego Mesa College, San Diego, CA, USA \\ ${ }^{10}$ Faculty of Biology, Technion - Israel Institute of Technology, Haifa, Israel \\ ${ }^{11}$ Department of Marine Chemistry and Geochemistry, Woods Hole Oceanographic Institution, Woods Hole, \\ MA, USA \\ ${ }^{12}$ Interdisciplinary Graduate Program in Quantitative Biosciences, Georgia Institute of Technology, Atlanta, \\ GA, USA \\ ${ }^{13}$ Adobe, San Jose, CA, USA \\ ${ }^{14}$ GEOMAR Helmholtz Centre for Ocean Research, Kiel, Germany \\ ${ }^{15}$ Laboratory of Applied Evolutionary Biology, Department of Medical Microbiology, Academic Medical Centre, \\ University of Amsterdam, Amsterdam, The Netherlands \\ ${ }^{16}$ School of Oceanography, University of Washington, Seattle, Washington, WA, USA \\ ${ }^{\dagger}$ These authors contributed equally. \\ *Corresponding authors: sjbeckett@gatech.edu, david.demory@biosci.gatech.edu, jsweitz@gatech.edu
}

\begin{abstract}
Marine ecosystem models often consider temporal dynamics on the order of months to years, and spatial dynamics over regional and global scales as a means to understand the ecology, evolution, and biogeochemical impacts of marine life. Large-scale dynamics are themselves driven over diel scales as a result of light-driven forcing, feedback, and interactions. Motivated by high-frequency measurements taken by Lagrangian sampling in the North Pacific Subtropical Gyre, we develop a hierarchical set of multitrophic community ecology models to investigate and understand daily ecological dynamics in the near-surface ocean including impacts of light-driven growth, infection, grazing, and phytoplankton size structure. Using these models, we investigate the relative impacts of viral-induced and grazing mortality for Prochlorococcus; and more broadly compare in silico dynamics with in situ observations. Via model-data fitting, we show that a multi-trophic model with size structure can jointly explain diel changes in cyanobacterial abundances, cyanobacterial size structure, viral abundance, viral infection rates, and grazer abundances. In doing so, we find that a significant component (between $5 \%$ to 55\%) of estimated Prochlorococcus mortality is not attributed to either viral lysis (by T4or T7-like cyanophage) or grazing by heterotrophic nanoflagellates. Instead, model-data integration suggests a heightened ecological relevance of other mortality mechanisms - including grazing by other predators, particle aggregation, and stress-induced loss mechanisms. Altogether, linking mechanistic multitrophic models with high-resolution measurements provides a route for understanding of diel origins of large-scale marine microbial community and ecosystem dynamics.
\end{abstract}


bioRxiv preprint doi: https://doi.org/10.1101/2021.06.15.448546; this version posted June 16, 2021. The copyright holder for this preprint

\section{Introduction}

Highly resolved surface ocean observations suggest that diel light rhythms drive repeatable changes in the abundance of ubiquitous cyanobacteria at the base of the microbial food web, including both Prochlorococcus and Synechococcus $[1,2]$. Cyanobacterial population dynamics are influenced by both nutrients and light availability $[2,3,4,5,6,7,8]$ as well as by density- and size-dependent feedback processes with other components of the community $[9,10,11,12,13,14,15]$. These interactions lead to diel oscillations, including in grazing rates, viral abundances, viral infection rates, and viral activity [16, 17, 18, 19, 20, 21]. The emergence of diel rhythms in abundances and process rates raises the question: how does light-driven growth of photoautotrophs over day-night cycles influence oscillations of other microbial populations and ecosystem processes? Resolving this question is challenging because it is often hard to disentangle process from pattern, e.g., reduced population growth and/or increased mortality can have the same net effect on cyanobacterial abundances. This type of identifiability problem is inherent to prior efforts to model size-structured phytoplankton growth with generic loss terms $[2,9,10]$. The identifiability problem is compounded by the fact that daily rhythms of microbes are also entrained, in part, with oscillatory day-night light forcing. In this study, we set out to use an ecological modeling framework, combined with field observations that go beyond cyanobacterial population measurements, as a means to understand how observed rhythms in Prochlorococcus dynamics influence and are influenced by rhythms of other populations in the microbial community in the North Pacific Subtropical Gyre (NPSG).

The NPSG is an oligotrophic system numerically dominated by the unicellular cyanobacteria Prochlorococcus, the most abundant phototroph in the global oceans [22]. Grazers and viruses are hypothesised to be the dominant drivers of Prochlorococcus loss [23, 24]. However estimating the relative contribution of viral-induced mortality and grazing-induced loss remains challenging [20,25, 26, 27, 28]. We focus our study on a near-surface Lagrangian parcel of water in the NPSG, which was sampled at $15 \mathrm{~m}$ depth over the course of ten days in summer 2015. Sampling on this expedition was performed at high time resolution (i.e., at four hour intervals for some components and nearly continuously for others). Related work from this cruise using the cellular iPolony method estimates that viruses, despite being highly abundant, may contribute to approximately $5 \%$ or less of total Prochlorococcus cell losses per day [20]. Congruently, using quota based reasoning, grazing by heterotrophic nanoflagellates could potentially account for the majority of Prochlorococcus cell losses per day [21], but this method cannot rule out the potential for significantly lower rates of grazing. We note that cruise data show clear repeatable periodicity in average Prochlorococcus cell volume, which peaks close to dusk, and cell abundance, which peaks during nighttime. Population abundances of heterotrophic nanoflagellates oscillate as does the fraction of cells infected by of T4- and T7-like viruses [20, 21]; suggesting the potential for emergent synchronization.

Here, we synthesise and integrate data from the 2015 cruise; augmented by the development, fitting and comparison with multi-trophic models. Our primary aim is to understand how mechanistic interactions between cyanobacteria, viruses, and grazers explain the observed diel variation in population abundances, process rates, and aggregate community dynamics in a model ocean ecosystem. To do so, we developed a hierarchical set of nonlinear dynamic models of microbial interactions spanning the cyanobacterium Prochlorococcus, heterotrophic nanoflagellate grazers and T4- and T7-like cyanophages in an oscillating light environment, and including phytoplankton size structure. These models combine principles of microbial interactions (including virus-microbe interactions) $[28,29,30,31,32,33]$ with size-structured models of phytoplankton growth $[2,7,9,10,12,13,34,35,36]$. We use these models to examine a series of related questions: how is the system expected to behave over diel timescales and how does light driven forcing of cyanobacterial growth affect size-dependent interactions between marine prey and predators? To do so, we compare in silico ecological rhythms with in situ ecological rhythms as a means to identify whether mechanistic representations of feedback can recapitulate observed rhythms and, if so, to what extent we can disentangle the relative contribution of viral-induced lysis and grazing to total Prochlorococcus mortality. Indeed, as we show, model-data integration suggests that the tight coupling of Prochlorococcus growth and loss over diel cycles may not be controlled only by cyanophages and heterotrophic grazers, but that additional factors are at play, raising new questions on governing mechanisms at the base of the marine food web. 

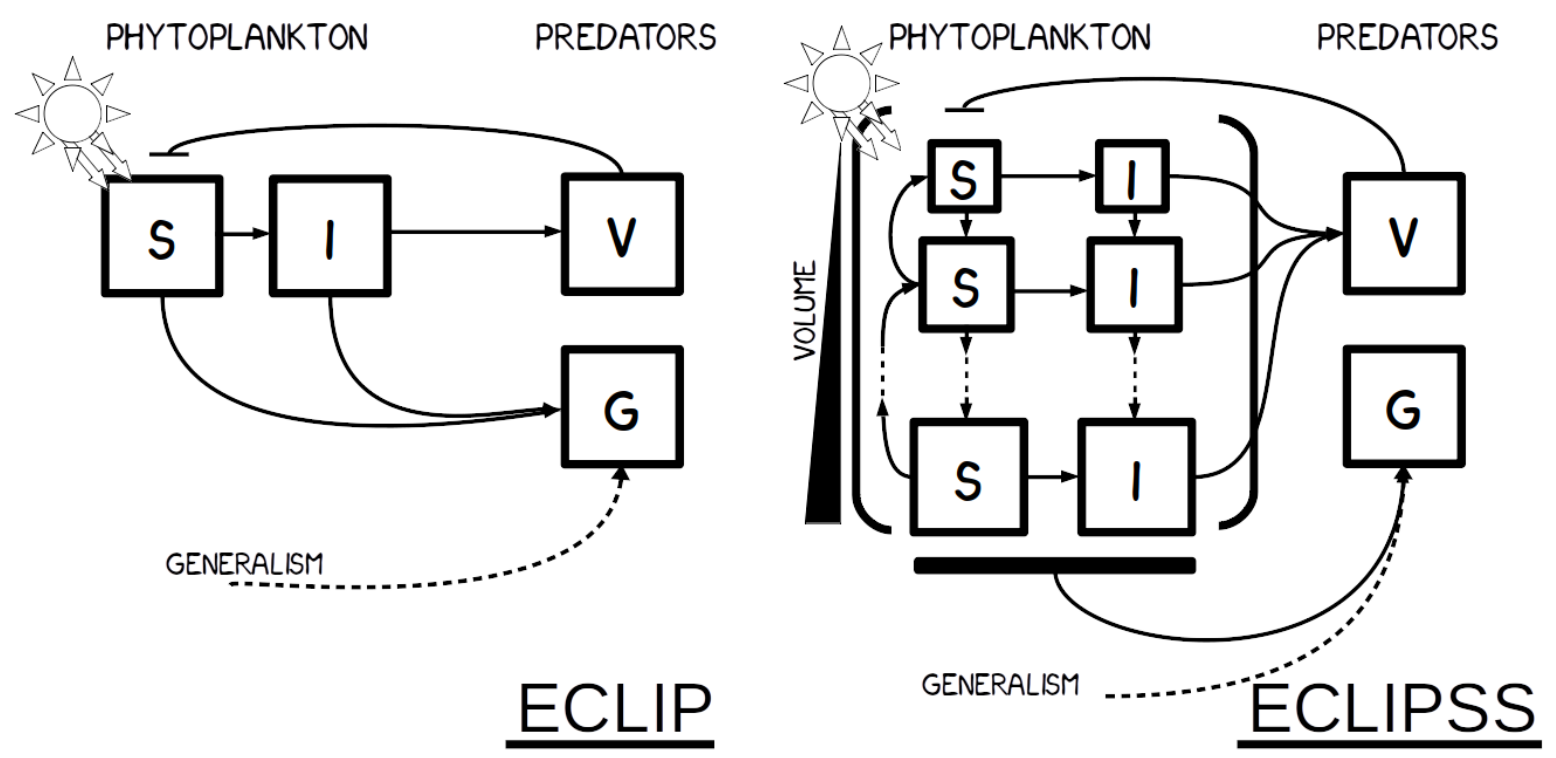

Figure 1: Community ecological models of viral and grazer mediated predation. Phytoplankton are structured by viral infection status; either susceptible $(S)$ or infected $(I)$. Susceptible phytoplankton can become infected upon encountering viruses $(V)$. Infected cells produce virions which are released into the environment upon viral-induced lysis. Both susceptible and infected cells are prone to grazing pressure from grazers $(G)$. Additionally, grazers may have a generalist strategy (e.g., grazing on heterotrophs, mixotrophs and phytoplankton not represented by $S$ and $I$ ) denoted by the dotted line. a) the ECLIP model b) the ECLIPSS model in which phytoplankton are additionally structured by size. Three size classes are graphically presented; more could be included as denoted by the dotted lines.

\section{Modeling Framework}

\subsection{Overview of Model Structure}

We develop two related models of an Ecological Community driven by Light including Infection of Phytoplankton, with and without Size Structure, which we term ECLIP and ECLIPSS, respectively. The first model includes dynamics of Prochlorococcus, grazers, and viruses (ECLIP). The second model extends this model to include Prochlorococcus size structure (ECLIPSS). These models include phytoplankton division and loss, where the loss arises due to a combination of grazing, viral lysis, and other factors. The ECLIPSS model also includes a phytoplankton growth term and explicit accounting for variation in cell size. In both models, viruses denote abundances of a focal set of T4- and T7-like cyanophages which are known to primarily infect Prochlorococcus. The grazers represent heterotrophic nanoflagellates which can feed on multiple prey types [37], however the primary food source for heterotrophic nanoflagellates may be Prochlorococcus [21]. As a result, we introduce flexibility in our model framework to account for whether or not Prochlorococcus constitutes the primary source of food for the observed grazer class. To assess this uncertainty we investigated models of two grazer strategies, with either a "specialised" grazer class that only consumes Prochlorococcus or a "generalised" grazer class that includes additional prey sources, e.g., heterotrophic bacteria which are not explicitly integrated into the models. Mixotrophic nanoflagellates [38] were observed at the study site, but are thought to contribute less to the grazing pressure on the bacterial community compared to heterotrophic nanoflagellates [21]. As it was not possible to differentiate measurements of mixotrophic nanoflagellates from measurements of phototrophic nanoflagellates [21] we choose to focus our attention on grazing by heterotrophic nanoflagellates. In both models, we search for sets of ecological parameters that are biologically feasible and use model-data integration approaches to identify parameter sets that generate dynamics consistent with the observed population dynamics in the NPSG. Details of ECLIP, ECLIPSS, and size structured assumptions follow. A complete description of the model structure and justifications for functional and parameter choices are found in the Supplementary Methods. 
bioRxiv preprint doi: https://doi.org/10.1101/2021.06.15.448546; this version posted June 16,2021 . The copyright holder for this preprint (which was not certified by peer review) is the author/funder, who has granted bioRxiv a license to display the preprint in perpetuity. It is made available under aCC-BY 4.0 International license.

\subsection{Ecological model of phytoplankton communities with viral and grazer mediated predation (ECLIP)}

The ECLIP model represents Prochlorococcus cell division as a light-driven process (where cell division is expected to occur at night $[2,39]$ ) and Prochlorococcus cell losses are controlled by viral lysis, grazing, and other density-dependent factors (Figure 1a). The Prochlorococcus population is structured by two states of infection: cells that are susceptible to viral infection $(S)$ and cells that are infected $(I)$ by viruses $(V)$. Grazers $(G)$ feed indiscriminately on both on $S$ and $I$ classes. The dynamics of the abundances of $S, I, V$ and $G$ over time are described by the following system of equations:

$$
\begin{aligned}
& \frac{d S}{d t}=\overbrace{\mu(t) S}^{\text {division }}-\overbrace{m_{p 1} S-m_{p 2} S(S+I)}^{\text {losses }}-\overbrace{\phi S V}^{\text {infection }}-\overbrace{\psi S G}^{\text {grazing }} \\
& \frac{d I}{d t}=\overbrace{\phi S V}^{\text {infected }}-\overbrace{m_{p 1} I-m_{p 2} I(S+I)}^{\text {losses }}-\overbrace{\eta I}^{\text {viral-lysis }}-\overbrace{\psi I G}^{\text {grazing }} \\
& \frac{d V}{d t}=\overbrace{\beta \eta I}^{\text {viral production }}-\overbrace{\phi(S+I) V}^{\text {adsorption }}-\overbrace{m_{v 1} V}^{\text {viral losses }}-\overbrace{m_{v 2} V^{2}}^{\text {higher-order losses }} \\
& \frac{d G}{d t}=\overbrace{\frac{N_{P}}{N_{G}} \psi(S+I) G}^{\text {grazing }}-\overbrace{m_{g 1} G}^{\text {specialist/generalist grazing }}-\overbrace{m_{g 2} G^{2}}^{\text {higher-order losses }},
\end{aligned}
$$

where

$$
\mu(t)=\mu_{\text {ave }}\left(1+\delta_{\mu} \sin \left(2 \pi\left(t+\delta_{t}\right)\right)\right) .
$$

Prochlorococcus have a diel-driven population division rate $\mu(t)$ whose proportional amplitude and phase are set by parameters $\delta_{\mu}$ and $\delta_{t}$, and $\mathrm{t}=0$ represents 06:00:00 local time (where $\mathrm{t}$ is measured in days). To aid model fitting we constrain $\delta_{t}$ such that peak division rate occurs at night. Prochlorococcus have a linear loss rate $m_{p 1}$ and a nonlinear loss rate, $m_{p 2}$, dependent on total phytoplankton abundance to implicitly represent niche competition [40]. Viruses infect susceptible Prochlorococcus at a rate $\phi$ and release $\beta$ new virions into the environment upon cellular lysis following the latent period (defined by the reciprocal of the lysis rate as $\frac{1}{\eta}$ ). Grazing upon Prochlorococcus is non-preferential with respect to infection status and occurs at a rate $\psi$ with a Gross Growth Efficiency (GGE) $\epsilon$ proportional to the fraction of nitrogen contents in a Prochlorococcus cell $\left(N_{P}\right)$ and a grazer $\left(N_{G}\right)$. We introduce $m_{g 1}$ as a parameter to denote whether grazers act as specialists or generalists, where the term represents net additional gains to the grazer from non-Prochlorococcus prey sources after accounting for respiratory costs. We represent a specialist strategy via $m_{g 1} \geq 0$, assuming that Prochlorococcus cells are the main source of grazer sustenance. In contrast, we represent a generalist strategy via $m_{g 1}<0$, implying that grazers have a net positive growth rate even in the absence of $S$ or $I$ via the consumption of other phytoplankton, heterotrophic bacteria, or grazers (via intraguild predation). Grazer and viral losses are both characterised by a nonlinear loss term to avoid structurally biasing the model to favour one of these Prochlorococcus predators [28] and to avoid competitive exclusion. A full list of parameters and further details are shown in the Supplementary Information.

\subsection{Ecological model of phytoplankton communities including size structure (ECLIPSS)}

The ECLIPSS model is illustrated in Figure 1b; it represents a Prochlorococcus population structured by differences in cell size and infection status: cells that are susceptible to viral infection $(S)$ and cells that are infected $(I)$ by viruses $(V)$. Both $S$ and $I$ are grazed upon by a general grazing class $(G)$. $S, I, V$ and $G$ represent population abundances. The ecological dynamics can be written, for a discrete number of size classes in matrix form as: 
bioRxiv preprint doi: https://doi.org/10.1101/2021.06.15.448546; this version posted June 16, 2021. The copyright holder for this preprint (which was not certified by peer review) is the author/funder, who has granted bioRxiv a license to display the preprint in perpetuity. It is made available under aCC-BY 4.0 International license.

$$
\begin{aligned}
& \frac{d \overrightarrow{\boldsymbol{S}}}{d t}=2 \overbrace{\underline{\underline{B}} \overrightarrow{\boldsymbol{S}}}^{\text {birth }}-\overbrace{\underline{\underline{\boldsymbol{D}} \overrightarrow{\boldsymbol{S}}}}^{\text {division }}+\overbrace{\underline{\underline{\boldsymbol{R}(E)}}}^{\text {growth }}-\overbrace{\underline{\underline{\boldsymbol{\lambda}(E)}} \overrightarrow{\underline{\boldsymbol{S}}}}^{\text {respiration }}-\overbrace{m_{p 1} \overrightarrow{\boldsymbol{S}}-m_{p 2} \overrightarrow{\boldsymbol{S}} M}^{\text {losses }}-\overbrace{\overrightarrow{\boldsymbol{\phi}} \overrightarrow{\boldsymbol{S}} V}^{\text {infection }}-\overbrace{\overrightarrow{\boldsymbol{\psi}} \overrightarrow{\boldsymbol{S}} G}^{\text {grazing }} \\
& \frac{d \overrightarrow{\boldsymbol{I}}}{d t}=\overbrace{\underline{\underline{\boldsymbol{R}(E)}}}^{\text {growth }}-\overbrace{\underline{\underline{\boldsymbol{\lambda}(E) \boldsymbol{I}}}}^{\text {respiration }}-\overbrace{m_{p 1} \overrightarrow{\boldsymbol{I}}-m_{p 2} \overrightarrow{\boldsymbol{I}} M}^{\text {losses }}+\overbrace{\overrightarrow{\boldsymbol{\phi}} \overrightarrow{\boldsymbol{S}} V}^{\text {infected }}-\overbrace{\overrightarrow{\boldsymbol{\psi}} \overrightarrow{\boldsymbol{I}} G}^{\text {grazing }}-\overbrace{\eta \overrightarrow{\boldsymbol{I}}}^{\text {viral-lysis }} \\
& \frac{d V}{d t}=\overbrace{\beta[\eta \overrightarrow{\boldsymbol{I}}]}^{\text {viral production }}-\overbrace{\overrightarrow{\boldsymbol{\phi}} \overrightarrow{\boldsymbol{S}} V-\overrightarrow{\boldsymbol{\phi}} \overrightarrow{\boldsymbol{I} V}}^{\text {adsorption }}-\overbrace{m_{v 1} V}^{\text {viral losses }}-\overbrace{m_{v 2} V^{2}}^{\text {higher-order losses }} \\
& \frac{d G}{d t}=\overbrace{\epsilon\left[\overrightarrow{\boldsymbol{N}}_{\boldsymbol{S}} \overrightarrow{\boldsymbol{\psi}}(\overrightarrow{\boldsymbol{S}}+\overrightarrow{\boldsymbol{I}})\right] \frac{G}{N_{G}}}^{\text {grazing }}-\overbrace{m_{g 1} G}^{\text {specialist/generalist grazing }}-\overbrace{m_{g 2} G^{2}}^{\text {higher-order los }}
\end{aligned}
$$

where vectors are shown in bold and accented by right arrows, and matrices are capitalised, bold and double underlined. Total Prochlorococcus carbon biomass is defined as $M=\sum\left(\overrightarrow{\boldsymbol{C}_{\boldsymbol{S}}}(\overrightarrow{\boldsymbol{S}}+\overrightarrow{\boldsymbol{I}})\right)$, where the carbon biomass of a Prochlorococcus cell is denoted as $\vec{C}_{\boldsymbol{S}}$. Both $\vec{C}_{\boldsymbol{S}}$ and the nitrogen biomass of a cell, $\vec{N}_{\boldsymbol{S}}$, are cell size-dependent (see Supplementary Information S1). The nitrogen biomass of a grazer cell is denoted as $N_{G}$. For simplicity, time dependencies on incoming photosynthetically active radiation, $E$, and biological state variables $S, I, V$ and $G$ are suppressed. A full list of parameters and further details are detailed in Supplementary Information S1. Key differences between the ECLIP and ECLIPSS models are that ECLIP has a sinusoidal diel-driven division rate, while in ECLIPSS we incorporate a light response that drives cellular volumetric growth and respiration (both absent in ECLIP). In ECLIPSS division rate is size-dependent such that a division event creates two daughter cells each with a volumetric size equal to half that of the mother cell. Additionally, in ECLIPSS, we model size-dependent encounter rates between Prochlorococcus and heterotrophic nanoflagellate grazers $(\vec{\psi})$, and T4- and T7-like cyanophages $(\vec{\phi})$.

\section{Results}

\subsection{Ecological model of phytoplankton communities with viral and grazer mediated predation (ECLIP) and model-data integration}

To explore the potential coexistence dynamics of Prochlorococcus, viruses and grazers, we first attempted to fit the ECLIP model using a Markov chain Monte Carlo (MCMC) approach given parameter bounds in biologically realistic ranges (see Table S2 for parameters and the Supplementary Information S2 for information on the MCMC fitting procedure). Since our data spans several orders of magnitude, and to avoid preferential fitting of a particular timeseries, we define error as the sum of the average relative differences between the model and empirical timeseries for each signal (Prochlorococcus cells, \%-infected Prochlorococcus cells, T4- and T7- like cyanophages, and heterotrophic nanoflagellates), subject to a quadratic penalty (see details in Supplementary Information, equation S25). The models are fitted against detrended empirical data, so for visualisation we add this trend to the model simulations. The results from the best-fit specialist and generalist ECLIP model are shown in Figure 2. Both classes of ECLIP models were able to reproduce the magnitudes of the different data signals and produced fits with similar fitting error (see Figure S5). Hence, we find that a relatively simple multitrophic model can recapitulate multi-trophic populations dynamics in the NPSG.

Despite the strong agreement with population dynamics, the specialist and generalist models differ significantly in the posterior parameter values identified by the MCMC procedure (see Figure S5). Some life-history traits converge to similar values in parameter space, such as the phasing of division, which corresponds to the peak division rate occurring between 00:00:00 and 00:30:00. However, modeled Prochlorococcus abundances did not fit the phasing of the empirical data without constraining the model to ensure peak division rate occurs at night. Prochlorococcus division is expected to peak at night after daytime photosynthesis-driven growth. The failure of ECLIP to identify this phasing provides motivation for including a more mechanistically driven model of division (explored in the next section). In other cases, MCMC parameter distributions appear bimodal (e.g. adsorption rates, lysis rates), multi-modal (e.g. grazing encounter rates), some with no clear mode (e.g. GGE), and others that differ between specialist and generalist models. For example, specialist models tend to have a larger lysis rate and grazing gross growth efficiency than do generalist models (see Supporting Information Section S2). Altogether, these findings suggest that the ECLIP model exhibits parameter entanglement and "sloppiness" [41], i.e. 
bioRxiv preprint doi: https://doi.org/10.1101/2021.06.15.448546; this version posted June 16,2021 . The copyright holder for this preprint (which was not certified by peer review) is the author/funder, who has granted bioRxiv a license to display the preprint in perpetuity. It is made available under aCC-BY 4.0 International license.
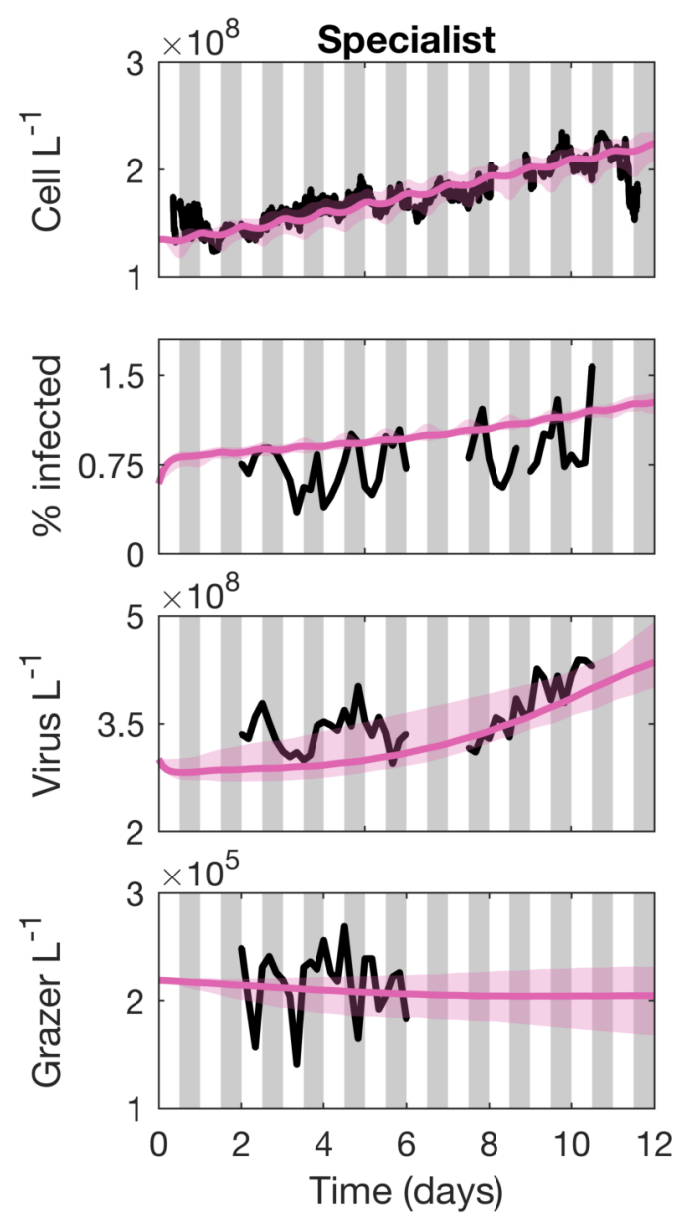
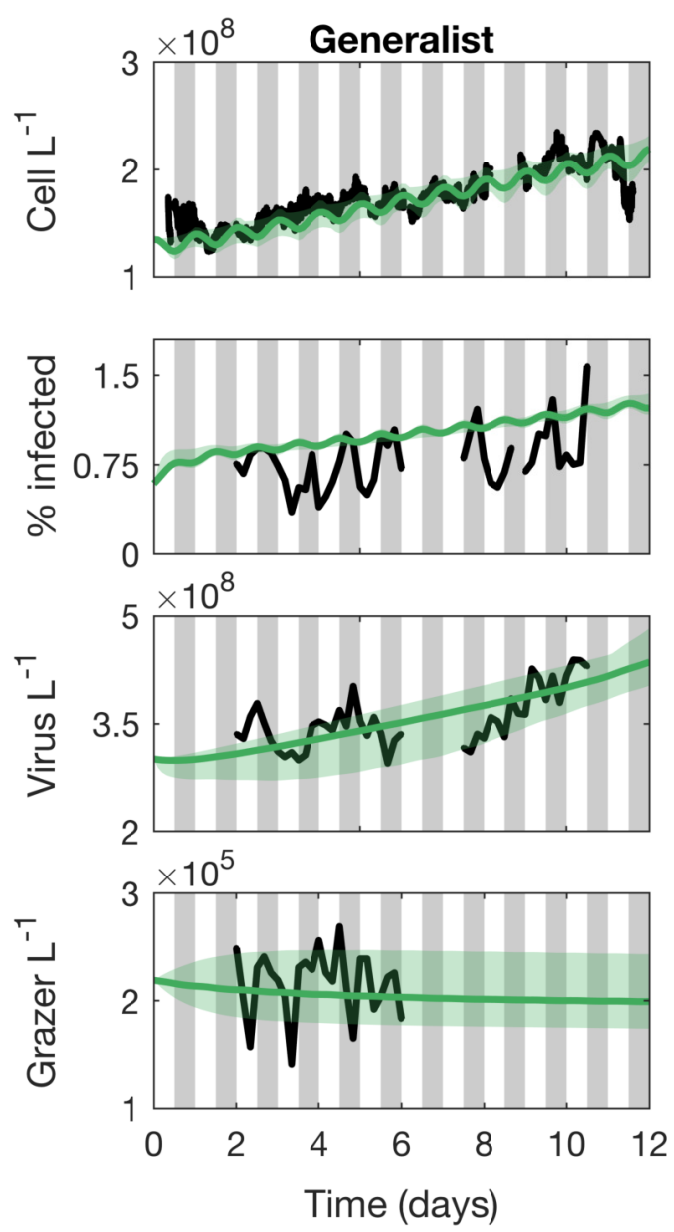

Figure 2: Specialist and generalist ECLIP model fit to empirical data. The best fitting specialist (left) in pink and generalist (right) in green ECLIP models are compared against empirical data in black. Model lines represent the median MCMC solution within the full range of solutions found by the converged chains shown as bands. Data signals include Prochlorococcus cell abundances (top), the percentage of infected Prochlorococcus cells, the abundance of free viruses and the abundance of heterotrophic nanoflagellate grazers (bottom). The models were fitted against detrended data; for visualisation we have added these trends to the model solutions. Grey bars indicate hours of darkness.

many parameter sets can lead to similar system behaviour. Further evidence for sloppiness is suggested by the parameter variability between different MCMC chains which all exhibited small and similar fitting errors. We interpret these findings to mean that despite the ability of ECLIP to recapitulate baseline dynamics (but not necessarily oscillation features of cells and infected cells over the diel cycle), we must be cautious in conflating fits with mechanism. Instead, the parameter sloppiness suggests the need to include additional data types (e.g., Prochlorococcus size structure) in order to differentiate between biological mechanisms (e.g., the relative contributions of lysis, grazing, or other factors to phytoplankton loss).

\subsection{Size-structured ecological model (ECLIPSS) and model-data integration}

The size-structured ECLIPSS model includes dynamics of size-structured susceptible and infected Prochlorococcus cells, cyanophages and heterotrophic nanoflagellates. Hence, in identifying parameters within ECLIPSS we augment the abundances of total cells, viruses, and heterotrophic nanoflagellates with the mean average volume of Prochlorococcus (as measured using SeaFlow; see Materials and Methods). We simulate the models using 20,000 parameter sets obtained by Latin Hypercube sampling (LHS) in biologically realistic ranges. Of these, 400 simulations produced feasible results (those that lead to stable coexistence of Prochlorococcus, cyanophages and grazers) under the specialist model and 1,094 simulations produced feasible results under the generalist model. These low rates of feasibility given random 
bioRxiv preprint doi: https://doi.org/10.1101/2021.06.15.448546; this version posted June 16, 2021. The copyright holder for this preprint (which was not certified by peer review) is the author/funder, who has granted bioRxiv a license to display the preprint in perpetuity. It is made available under aCC-BY 4.0 International license.

parameter sampling are consistent with prior analyses of a multitrophic model without light-driven dynamics [29]. We used a subset of model runs with the smallest total error to constrain our parameter ranges; and used these to generate 10,000 new parameter sets (see Supplementary Text). Of these, 1,886 simulations produced feasible results under the specialist model and 2,512 simulations produced feasible results under the generalist model. The best fit from the generalist model has an error of 0.1584 , whilst the best fit from the specialist model has an error of 1.0414 (Supplementary Information, Figure S12). We cannot directly compare fitting error between ECLIP and ECLIPSS models due to the addition of fitting ECLIPSS to cell volume, however the errors in the ECLIPSS models are larger per population type on average than those found in the optimised ECLIP models. We note these fits improve upon those found in the initial parameterisation of ECLIPSS (Supplementary Information, Table S1) shown in Supplementary Information Figure S4.
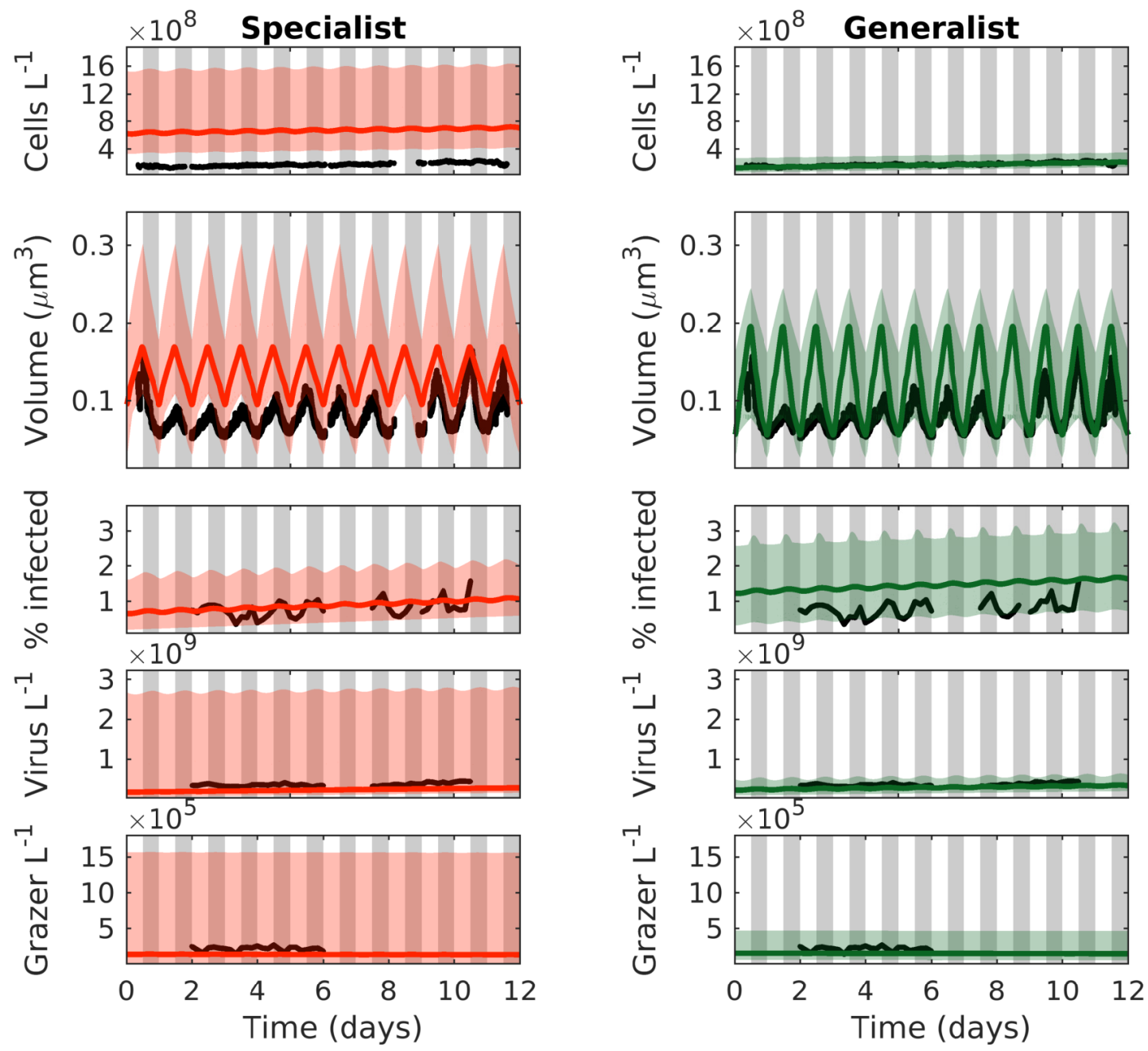

Figure 3: The best fitting specialist and generalist ECLIPSS models. The best fitting specialist (left) in red and generalist (right) in green ECLIPSS models are denoted in solid lines and enveloped in the bounds of the best ten fitting models and compared against empirical data in black. Data signals that are compared to the data for fitting are Prochlorococcus cell abundance (top), mean Prochlorococcus cell volume, the percentage of infected Prochlorococcus cells, the abundance of free viruses and the abundance of heterotrophic nanoflagellate grazers. The figure shows the bounds and mean of the top ten specialist and generalist models. The models were fitted to detrended data; for visualisation we have added these trends to the model solutions. Grey bars indicate hours of darkness.

The agreement between model and data in Figure 3 suggest that the core feedback mechanisms are 
bioRxiv preprint doi: https://doi.org/10.1101/2021.06.15.448546; this version posted June 16, 2021. The copyright holder for this preprint (which was not certified by peer review) is the author/funder, who has granted bioRxiv a license to display the preprint in perpetuity. It is made available under aCC-BY 4.0 International license.

sufficient to jointly explain Prochlorococcus abundances and size structure, viral infection rates, viral abundances, and grazer abundances at sub-daily resolution. Nonetheless, differences appear between the best fitting specialist and generalist model states and the data; as well as between the model outcomes themselves. In the specialist model Prochlorococcus cell abundances appear about an order of magnitude larger than those observed and the model population has a larger average volume than that found in the data. On the other hand, the generalist model broadly captures the magnitude of Prochlorococcus cell abundance; and captures the diel variations in average cell volume. Both ECLIPSS models appear close to the observed magnitudes of $\approx 1 \%$ infected cells [20]. Both ECLIPSS models were broadly able to characterise the magnitudes of free T4- and T7-like cyanophages and heterotrophic nanoflagellate grazer abundances, though there was large variation amongst the best fitting specialist models. We note that the model predicted dynamics of Prochlorococcus, free virus abundance, heterotrophic nanoflagellate abundance, and the percentage of infected cells do not always recapitulate the magnitude of diel oscillations observed. This gap may point to direct light-mediated modulation of life history traits and behavior $[16,17,18,19,20,21]$, and/or unaccounted for feedback mechanisms in the model structure. Like our analysis of ECLIP, we find differences in parameter sets between the best fitting generalist and specialist ECLIPSS models that is then recapitulated via analysis of the full suite of coexisting LHS parameter sets (Supplementary Information, Figure S9 and S12-S15) Hence, rather than conclude that a particular parameter set provides the most explanatory power to observed patterns, we seek to identify mechanisms common to those parameter sets that fit the data nearly equally well.

\subsection{Partitioning the daily losses of Prochlorococcus between top-down and other effects}

We revisit the best fitting specialist and generalist ECLIP and ECLIPSS models shown in Figures 2 and 3 to analyse the predicted partitioning of mortality among grazing by heterotrophic nanoflagellates, viralinduced lysis by T4- and T7-like cyanophages, and other sources. We expect that grazing may represent a larger proportion of losses in the models in which heterotrophic nanoflagellates act as specialists such that Prochlorococcus are their only prey source. For ECLIP we evaluate models from across the best chains, which all had small fitting errors; while in ECLIPSS, due to a paucity of model solutions with low error, we focus our analysis on models with a fitting error less than 2 (the top 13 specialist and 154 generalist models).

In Figure 4 we compared our model-inferred estimates of relative mortality with additional independent estimates from field based (iPolony measurements and fluorescently labelled bacterial (FLB) uptake estimates) or theoretical (encounter and quota) methods (see details in Supplementary Information S4). Theoretical estimates via the encounter and quota methods have significant variability due in part to uncertainties in life history traits. As such, viral lysis or grazing could potentially explain daily Prochlorococcus losses. However, direct estimates suggest that both viral-induced lysis by T4- and T7-like cyanophages and grazing by heterotrophic nanoflagellates only contribute a comparatively small amount to Prochlorococcus cell losses. We estimate that less than 35\% of Prochlorococcus cell losses are explained by the combination of viral-induced lysis by T4- and T7-like cyanophages (estimated by iPolony) and grazing by heterotrophic nanoflagellates (estimated by FLB). Across models, we find that grazing makes up a larger proportion of Prochlorococcus cell losses in models in which heterotrophic nanoflagellates act as specialist consumers. In general, we find that viral-induced lysis is responsible for only a small proportion of losses in both models in agreement with Mruwat et al. [20]. Grazing by heterotrophic nanoflagellates, by contrast, made up the majority of Prochlorococcus cell losses across both the ECLIP models and in the specialist grazer ECLIPSS model. However, viral-induced lysis was inferred to be larger in the generalist ECLIPSS model, while grazing was much smaller - and more in line with estimates made via FLB measurements - relative to the other models. Combining model-data integration with direct measurements of top-down effectors, we found that the model-inferred combination of viral-induced lysis by T4- and T7-like cyanophages and grazing by heterotrophic nanoflagellates typically do not sum up to equal total Prochlorococcus cell losses on a daily basis.

Instead, our model-data integration suggests that other sources of Prochlorococcus cell losses are nonnegligible, accounting for between $5 \%$ and $55 \%$ across the different model types. One possibility is that mortality partitioning could be linked to how quickly Prochlorococcus cells are expected to turnover in the NPSG. We note that the best set of models supports a large range of per capita Prochlorococcus cell loss rates of between nearly 0 and 1.1 per day; suggesting that perhaps the variability in other loss rates are coupled to magnitude of the estimated birth/death rates. However, contrary to this hypothesis, we do not have evidence linking total loss rates and mortality partitioning between viral-induced lysis, heterotrophic 
bioRxiv preprint doi: https://doi.org/10.1101/2021.06.15.448546; this version posted June 16, 2021. The copyright holder for this preprint (which was not certified by peer review) is the author/funder, who has granted bioRxiv a license to display the preprint in perpetuity. It is made available under aCC-BY 4.0 International license.
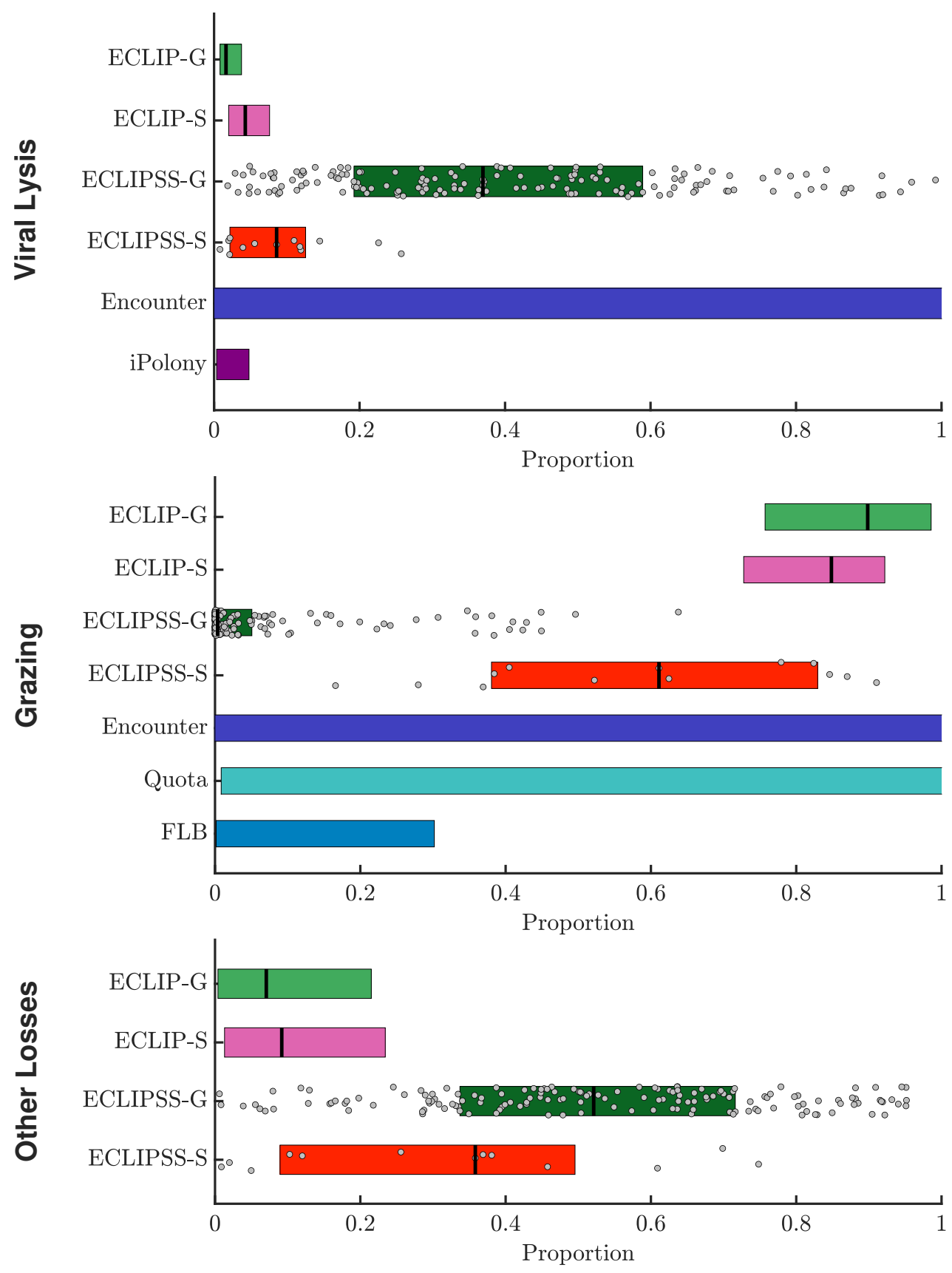

Figure 4: Relative importance of viral lysis, grazing, and other effects on total Prochlorococcus mortality. The proportion of mortality partitioned between viral-induced lysis (top panel), grazing (middle panel), and other (bottom panel) sources for the best ECLIP specialist (ECLIP-S) and generalist (ECLIP-G) and ECLIPSS specialist (ECLIPSS-S) and generalist (ECLIPSS-G) models and other measures of relative mortality. For ECLIP the results from all chains are shown. For ECLIPSS only models with a fitting error less than 2 are included (and are additionally shown as individual points). Bars in these panels denote mortality rate proportions associated with the best ECLIP and ECLIPSS models marked by their 25,50 and $75 \%$ quantiles. Other measures of relative mortality are given via theoretical encounter rates and quota based estimates, direct measurements of viral infection (iPolony), and Fluorescently Labelled Bacteria (FLB) incubation measurements (see Supplementary Information Section S4 for details).

nanoflagellate grazing and other processes in either the ECLIP or ECLIPSS models (Supplementary Information, Figure S16). Taken together, model-data integration suggests that viral-induced lysis accounts for a relatively small proportion of Prochlorococcus cell losses in the NPSG. Model results also suggest that the sum of losses via viral-induced lysis and heterotrophic nanoflagellate grazing do not account for 
bioRxiv preprint doi: https://doi.org/10.1101/2021.06.15.448546; this version posted June 16, 2021. The copyright holder for this preprint

the majority of Prochlorococcus cell losses - in contrast to prior work that generally aims to partition loss rates in terms of established top-down drivers. Together, both model-data fits and independent estimates of top-down mortality suggest that other forms of losses beyond grazing by heterotrophic nanoflagellates and lysis by T4/T7-like cyanophages may be critical in shaping daily phytoplankton rhythms.

\section{Discussion}

We developed and analysed two multitrophic community ecology models, ECLIP and ECLIPSS, consisting of Prochlorococcus, viruses, and grazers to investigate the feedback mechanisms and ecological drivers of oligotrophic ocean microbial population dynamics on diel timescales. Both ECLIP and ECLIPSS include light-driven phytoplankton growth, where phytoplankton can be infected and lysed by viruses, or grazed upon by nanoflagellate grazers. ECLIPSS explicitly incorporates phytoplankton size-structure including size-mediated division and encounter with viral and grazer predators, while ECLIP considers the ecological interactions independent of size-structure. We found that both ECLIP and ECLIPSS were capable of generating coexisting populations of cyanobacteria, viruses infecting cyanobacteria, and grazers, and that the suite of model solutions encompasses the population abundances observed in the NPSG (Supplementary Information, Figure S11). Despite strong agreement with data, we found that underlying process rates and life-history traits differed significantly amongst best-fitting ECLIP models. In an effort to resolve identifiability problems, we found that ECLIPSS was able to jointly explain the abundance dynamics of Prochlorococcus, virus particle abundances, infected cells, and grazers. By combining model-data fits with direct measurements of mechanistic interactions we infer that the combination of lysis and grazing does not account for daily Prochlorococcus losses. Instead, we find that a significant and potentially majority - of Prochlorococcus losses are due to other mechanisms beyond that of lysis by T4- and T7-like cyanophage and nanoflagellate grazing.

The development of a multitrophic model focused in on a portion of a complex, surface ecosystem. In doing so, we integrated our models with field observations to understand interactions of T4- and T7-like cyanophages as well as nanoflagellate grazers with Prochlorococcus, the most abundant phytoplankton at our study site. Prior work has assumed that Prochlorococcus is the predominant prey for heterotrophic nanoflagellate grazers - but such an assumption had the potential to bias interpretations of direct ingestion experiments (and the interpretation of total loss rates). Instead, it is likely that heterotrophic nanoflagellate grazers rely on other food sources as part of a generalist feeding strategy. To evaluate this possibility, the ECLIP framework included the potential for model outcomes to span generalist to specialist strategies. However, we found a critical identifiability problem: a broad range of model classes could explain population dynamics in the absence of size structure. These identifiability problems within the ECLIP framework prevented us from distinguishing whether heterotrophic nanoflagellates act primarily as specialist grazers of Prochlorococcus, or ingest a broader range of prey items. Turning to ECLIPSS, we found that assuming grazers are generalist, rather than specialists, leads to improvements in fit quality. Notably, ECLIPSS was able to recapitulate daily dynamics of total Prochlorococcus cell abundances and size structure, as well as top-down populations including the fraction of infected cells, T4- and T7-cyanophage abundances, and heterotrophic nanoflagellate grazer abundances.

Overall, the fit of model dynamics to NPSG measurements enabled us to examine how much of Prochlorococcus mortality can be ascribed to viral lysis, heterotrophic nanoflagellate grazing, or other sources. In partitioning Prochlorococcus mortality we found different outcomes across the different model scenarios and independent auxiliary estimates (Figure 4). Indirect estimates via encounter rate or quotabased theory are poorly constrained and are limited by our current knowledge of microbial ecological lifehistory traits. However, fitting dynamical models, ECLIP and ECLIPSS with the same initial parameter ranges, to the data resulted in more constrained mortality estimates. Both the ECLIP and ECLIPSS models predicted that other sources of mortality were likely important in explaining community diel patterns. Assuming that grazers function as generalists, we found that compatible model-data fits predict that other sources of mortality can account for over $50 \%$ of daily Prochlorococcus mortality. We found that direct estimates of mortality from grazing incubation experiments and infected cell measurements also provide evidence that heterotrophic nanoflagellate grazing and T4- and T7- like viral-induced mortality do not account for all Prochlorococcus losses in the NPSG. Quantifying the relative importance of mortality processes beyond conventional top-down effects (grazing and lysis) is critical for understanding how grazers and viruses contribute to mortality and energy transfer in marine microbial communities [2, 23, $24,28]$. 
bioRxiv preprint doi: https://doi.org/10.1101/2021.06.15.448546; this version posted June 16,2021 . The copyright holder for this preprint (which was not certified by peer review) is the author/funder, who has granted bioRxiv a license to display the preprint in perpetuity. It is made available under aCC-BY 4.0 International license.

Box 1 Potential mechanisms to explain other losses of Prochlorococcus

\section{Undercharacterised ecological interactions}

Mixotrophic nanoflagellates are expected to contribute to the "other" loss of Prochlorococcus, but measurements suggest this is a small contribution relative to the heterotrophic nanoflagellates [21, 42]. Unknown viruses (like RNA viruses), as well as other grazer types including larger consumers may be contributing to the 'other mortality' terms in our models. In addition, the model includes viral-induced and grazing-induced losses; however in both cases we utilize a contact-driven model, analogous to 'Type I' functional responses. Mechanistic changes in functional responses and/or responses to light may drive distinct interaction rates (and aggregate mortality) even given the same set of viruses and grazers.

\section{Aggregation and sinking of picoplankton}

Some losses may be due to Prochlorococcus aggregation, particle attachment, and subsequent sinking out. Picoplankton (and their viruses) have been suggested to be an important contributor to export in large scale analyses e.g. [43, 44], though Guidi et al. [44] suggest Synechococcus rather than Prochlorococcus abundances appear correlated to export. Additionally, less is known about the microscale processes that might lead to export contributions from picoplankton - Prochlorococcus cells can be grown and sustained in laboratory culture for month-long experiments, suggesting sedimentation of Prochlorococcus cells may be limited. Generally, conceptual models of ocean ecology do not include sinking out of picoplanktonic populations. However, particle aggregation could be stimulated via processes such as sloppy feeding or viral lysate [28, 45]. As viral lysate from picocyanobacteria is partially labile $[46,47]$ aggregation and sinking could be stimulated indirectly by viral lysate via heterotrophic bacterial growth. Particle attachment and aggregation could also be stimulated by TEP (Transparent exopolymer particles), which is produced in xenic Prochlorococcus cultures $[48,49]$. TEP production appears to be stimulated by high light intensity, characteristic of the surface ocean, and appears to be linked to loss rates [48].

\section{Physiological stress(es)}

Other potential loss mechanisms include physiological stress which can be induced, for example, by high-level irradiance associated with ultraviolet radiation [50, 51] and refraction of light through surface waves that could lead to photodamage via the flashing effect $[52,53]$. Other abiotic factors such as nutrient deficiency [54], metal toxicity [55, 56], and thermal variations [57] can also contribute to increased stress, though we do not expect thermal variations to be important in the NPSG. Stresses often result in the generation of reactive oxygen species, that cause oxidative stress and can lead to DNA damage. Reactive oxygen species are also used as a signalling pathway for programmed cell death in photosynthetic microbes $[58,59,60]$, though there is a lack of evidence for a programmed cell death pathway in Prochlorococcus and sympatric heterotrophic bacteria are thought to alleviate this type of stress $[61,62]$. We note that there is also a lack of evidence for toxin-antitoxin systems, which are typically common across bacteria and archaea and could act as a pathway to additional cell loss, in Prochlorococcus [63].

\section{Population heterogeneity}

Microbes experience senescence and aging, leading to intracellular accumulation of damage through their life cycle [64], which may lead to asymmetric division [65]. Unlike other microorganisms, Prochlorococcus does not have resting stages and rely on heterotrophic bacteria to survive nutrient starvation in cultures [66], though the types of heterotrophic bacteria they form associations with in situ differ from those found in culture which tend to be copiotrophic [67]. Heterogeneity within the Prochlorococcus population may mean there are differing mortality responses at the individual or strain-level vs. at the scale of total population. Prochlorococcus populations are combinations of ecotypes which respond differently to environmental stressors [68, 69, 70, 71, 72, 73]. Competition between these ecotypes and with other phytoplankton in the same niche (like Synechococcus or picoeukaryotes) may also increase stresses, especially in an oligotrophic environment like the NPSG where nutrients are limited. 
bioRxiv preprint doi: https://doi.org/10.1101/2021.06.15.448546; this version posted June 16, 2021. The copyright holder for this preprint

The finding that model-data fits impute other sources of mortality as quantitatively significant suggests that we may be missing important feedback mechanisms in our representation of marine surface community dynamics. Indeed, phytoplankton loss from the surface oceans is likely to include factors beyond grazing and viral-induced lysis $[74,75]$. In Box 1 we review some potential mechanisms that may contribute to the unaccounted losses of Prochlorococcus, including ecological feedback that leads to distinct functional and/or light-driven responses, aggregation and/or sinking, stress, population heterogeneity, as well as the possibility of having missed other sources of top-down mortality (e.g., uncharacterised viral infections or grazing by larger organisms). Similarly, our measurements may miss heterogeneities within the Prochlorococcus population that mask our ability to interpret mortality. Alternatively, we may be missing entire mechanisms of loss such as via particle aggregation and sinking out, or via physiological stresses on cells. Investigating whether alternative mechanisms of Prochlorococcus losses could be significant warrants future research, and may be critical to improving understanding of how biomass and nutrients are transferred through marine food webs.

Both the ECLIP and ECLIPSS modeling frameworks come with caveats, despite the inclusion of multiple populations and interaction types. First, we have focused on the impacts of direct, light-driven forcing of cyanobacterial division (in ECLIP) and growth leading to division (in ECLIPSS). Hence, oscillations arising in other components reflect a combination of instabilities that can arise in nonlinear population models as well as the cascading impacts of such oscillations on the community. Direct incorporation of diel impacts on grazing $[16,18,21]$ or viral traits (e.g., adsorption) $[76,19]$ may be required to mechanistically understand population dynamics on sub-daily timescales. Second, we have used two focal processes to examine ways that carbon and nutrients in basal picoplankton are transferred, e.g., up through the food chain via grazing or retained in the microbial loop due to viral lysis (aka the viral shunt) $[77,78]$. This dichotomy reflects a potential tension in the extent to which primary production stimulates the biological pump. Extensions to the current model might also examine the mechanistic process of export explicitly, whether through coupling grazing to the generation of particles and/or examining the extent to which viral lysis generates aggregates which can exported to the deep oceans via the viral shuttle [45, 79]. Finally, our work has implicated an accounting challenge in quantifying the balance of Prochlorococcus growth and losses. Despite the daily growth and division of cells, the overall abundance remains tightly constrained - our work suggests that this constraint may in fact depend on other factors beyond conventional mechanisms of loss ascribed to T4- and T7-like cyanophage and nanoflagellate grazers.

In summary, this multi-trophic modeling framework provides an opportunity to test the limits of our understanding of feedback mechanisms of microbial communities in the surface open ocean. In doing so, the model has provided additional support for the hypothesis that relatively high viral abundances can be compatible with relatively low infection (and mortality) rates, how grazer generalism may be key to understanding Prochlorococcus abundances, while also identifying a key direction for future work: identifying the potentially 'missing mortality' of phytoplankton at the base of the marine food web. In moving forward, in situ observations will be needed to probe aggregation and sinking, autolysis, programmed cell death, or other forms of loss of Prochlorococcus in the surface ocean and to understand the feedbacks of variation in cyanobacterial growth and loss in a changing ocean.

\section{Acknowledgements}

We thank the captain and crew of the R/V Kilo Moana for their effort and assistance on the Hawaii Ocean Experiment Legacy II cruise (KM1513); and we thank Jeremy Harris for code review. This work was supported by grants from the Simons Foundation (no. 549894 to J.R.C. and no. 329108 to E.V.A., D.A.C., D.L., M.J.F, A.E.W. and J.S.W). This is a contribution of the Simons Collaboration on Ocean Processes and Ecology (SCOPE).

\section{References}

[1] Daniel Vaulot and Dominique Marie. Diel variability of photosynthetic picoplankton in the equatorial Pacific. Journal of Geophysical Research: Oceans, 104(C2):3297-3310, 1999. 
[2] Francois Ribalet, Jarred Swalwell, Sophie Clayton, Valeria Jiménez, Sebastian Sudek, Yajuan Lin, Zackary I Johnson, Alexandra Z Worden, and E Virginia Armbrust. Light-driven synchrony of Prochlorococcus growth and mortality in the subtropical Pacific gyre. Proceedings of the National Academy of Sciences, 112(26):8008-8012, 2015.

[3] Ioannis Tsakalakis, Markus Pahlow, Andreas Oschlies, Bernd Blasius, and Alexey B Ryabov. Diel light cycle as a key factor for modelling phytoplankton biogeography and diversity. Ecological Modelling, 384:241-248, 2018.

[4] Sarah K Hu, Paige E Connell, Lisa Y Mesrop, and David A Caron. A hard days night: Diel shifts in microbial eukaryotic activity in the North Pacific Subtropical Gyre. Frontiers in Marine Science, 5:351, 2018.

[5] David G. Welkie, Benjamin E. Rubin, Spencer Diamond, Rachel D. Hood, David F. Savage, and Susan S. Golden. A hard day's night: Cyanobacteria in diel cycles. Trends in Microbiology, $27: 231-242,2018$.

[6] Kevin W. Becker, James R. Collins, Bryndan P. Durham, Ryan D. Groussman, Angelicque E. White, Helen F. Fredricks, Justin E. Ossolinski, Daniel J. Repeta, Paul Carini, E. Virginia Armbrust, and Benjamin A. S. Van Mooy. Daily changes in phytoplankton lipidomes reveal mechanisms of energy storage in the open ocean. Nature Communications, (9):5179, 2018.

[7] Kristen R Hunter-Cevera, Michael G Neubert, Robert J Olson, Alexi Shalapyonok, Andrew R Solow, and Heidi M Sosik. Seasons of Syn. Limnology and Oceanography, 2019.

[8] Martino E Malerba, Dustin J Marshall, Maria M Palacios, John A Raven, and John Beardall. Cell size influences inorganic carbon acquisition in artificially selected phytoplankton. New Phytologist, 2020 .

[9] Heidi M Sosik, Robert J Olson, Michael G Neubert, Alexi Shalapyonok, and Andrew R Solow. Growth rates of coastal phytoplankton from time-series measurements with a submersible flow cytometer. Limnology and Oceanography, 48(5):1756-1765, 2003.

[10] Kristen R Hunter-Cevera, Michael G Neubert, Andrew R Solow, Robert J Olson, Alexi Shalapyonok, and Heidi M Sosik. Diel size distributions reveal seasonal growth dynamics of a coastal phytoplankter. Proceedings of the National Academy of Sciences, page 201321421, 2014.

[11] Darcy AA Taniguchi, Peter JS Franks, and Francis J Poulin. Planktonic biomass size spectra: an emergent property of size-dependent physiological rates, food web dynamics, and nutrient regimes. Marine Ecology Progress Series, 514:13-33, 2014.

[12] Esteban Acevedo-Trejos, Gunnar Brandt, S Lan Smith, and Agostino Merico. PhytoSFDM version 1.0. 0: phytoplankton size and functional diversity model. Geoscientific Model Development, 9(11):4071-4085, 2016.

[13] Bingzhang Chen and Sherwood Lan Smith. CITRATE 1.0: Phytoplankton continuous traitdistribution model with one-dimensional physical transport applied to the North Pacific. Geoscientific Model Development, 11(1):467-495, 2018.

[14] David Talmy, Stephen J Beckett, Adam B Zhang, Darcy A A Taniguchi, Joshua S Weitz, and Michael J Follows. Contrasting controls on microzooplankton grazing and viral infection of microbial prey. Frontiers in Marine Science, 6:182, 2019.

[15] Daniele De Corte, Gabriela Paredes, Taichi Yokokawa, Eva Sintes, and Gerhard J. Herndl. Differential response of Cafeteria roenbergensis to different Bacterial and Archaeal prey characteristics. Microbial Ecology, 78:1-5, Nov 2018.

[16] Wai Ho Albert Ng and Hongbin Liu. Diel periodicity of grazing by heterotrophic nanoflagellates influenced by prey cell properties and intrinsic grazing rhythm. Journal of Plankton Research, 38(3):636-651, 2016.

[17] Frank O Aylward, Dominique Boeuf, Daniel R Mende, Elisha M Wood-Charlson, Alice Vislova, John M Eppley, Anna E Romano, and Edward F DeLong. Diel cycling and long-term persistence of viruses in the oceans euphotic zone. Proceedings of the National Academy of Sciences, 114(43):11446-11451, 2017. 
[18] Anna Arias, Enric Saiz, and Albert Calbet. Towards an understanding of diel feeding rhythms in marine protists: Consequences of light manipulation. Microbial Ecology, 79:64-72, 2020.

[19] David Demory, Riyue Liu, Yue Chen, Fangxin Zhao, Ashley R. Coenen, Qinglu Zeng, and Joshua S Weitz. Linking light-dependent life history traits with population dynamics for Prochlorococcus and cyanophage. mSystems, 5(2):e00586-19, 2020.

[20] Noor Mruwat, Michael C G Carlson, Svetlana Goldin, François Ribalet, Shay Kirzner, Yotam Hulata, Stephen J Beckett, Dror Shitrit, Joshua S Weitz, E. Virginia Armbrust, and Debbie Lindell. A single-cell polony method reveals low levels of infected Prochlorococcus in oligotrophic waters despite high cyanophage abundances. The ISME Journal, 15:41-54, 2021.

[21] Paige E. Connell, François Ribalet, E. Virginia Armbrust, Angelicque E. White, and David A. Caron. Diel oscillations in feeding strategies of heterotrophic and mixotrophic nanoplankton in the North Pacific Subtropical Gyre. Aquatic Microbial Ecology, 85:167-181, 2020.

[22] Fred Partensky, Wolfgang R Hess, and Daniel Vaulot. Prochlorococcus, a marine photosynthetic prokaryote of global significance. Microbiology and Molecular Biology Reviews, 63(1):106-127, 1999.

[23] Alexis L Pasulka, Ty J Samo, and Michael R Landry. Grazer and viral impacts on microbial growth and mortality in the southern California Current Ecosystem. Journal of Plankton Research, $37(2): 320-336,2015$.

[24] Kristina DA Mojica, Jef Huisman, Steven W Wilhelm, and Corina PD Brussaard. Latitudinal variation in virus-induced mortality of phytoplankton across the North Atlantic Ocean. The ISME Journal, 10(2):500, 2016.

[25] Stephen J Beckett and Joshua S Weitz. Disentangling niche competition from grazing mortality in phytoplankton dilution experiments. PLOS ONE, 12(5):e0177517, 2017.

[26] Albert Calbet and Enric Saiz. How much is enough for nutrients in microzooplankton dilution grazing experiments? Journal of Plankton Research, 40(2):109-117, 2017.

[27] Stephen J Beckett and Joshua S Weitz. The effect of strain level diversity on robust inference of virus-induced mortality of phytoplankton. Frontiers in Microbiology, 9:1850, 2018.

[28] David Talmy, Stephen J Beckett, Darcy A A Taniguchi, Corina P.D. Brussaard, Joshua S Weitz, and Michael J Follows. An empirical model of carbon transfer to marine viruses and zooplankton grazers. Environmental Microbiology, 21(6):2171-2181, 2019.

[29] Joshua S Weitz, Charles A Stock, Steven W Wilhelm, Lydia Bourouiba, Maureen L Coleman, Alison Buchan, Michael J Follows, Jed A Fuhrman, Luis F Jover, Jay T Lennon, et al. A multitrophic model to quantify the effects of marine viruses on microbial food webs and ecosystem processes. The ISME Journal, 9(6):1352, 2015.

[30] Marcos D Mateus. Bridging the gap between knowing and modeling viruses in marine systems-an upcoming frontier. Frontiers in Marine Science, 3:284, 2017.

[31] Michal Grossowicz, Dalit Roth-Rosenberg, Dikla Aharonovich, Jacob Silverman, Michael J Follows, and Daniel Sher. Prochlorococcus in the lab and in silico: the importance of representing exudation. Limnology and Oceanography, 62(2):818-835, 2017.

[32] Julia E Middleton, Joaquín Martínez Martínez, William H Wilson, and Nicholas R Record. Functional dynamics of Emiliania huxleyi virus-host interactions across multiple spatial scales. Limnology and Oceanography, 62(3):922-933, 2017.

[33] Kai W Wirtz. Physics or biology? Persistent chlorophyll accumulation in a shallow coastal sea explained by pathogens and carnivorous grazing. PLOS ONE, 14(2):e0212143, 2019.

[34] Ben A Ward, Jamie D Wilson, Ros M Death, Fanny M Monteiro, Andrew Yool, and Andy Ridgwell. EcoGEnIE 1.0: plankton ecology in the cGEnIE Earth system model. Geoscientific Model Development, 11(10):4241-4267, 2018.

[35] Annette M Hynes, Brad J Blythe, and Brian J Binder. An individual-based model for the analysis of Prochlorococcus diel cycle behavior. Ecological Modelling, 301:1-15, 2015. 
bioRxiv preprint doi: https://doi org/10.1101/2021.06.15.448546; this version posted June 16,2021 . The copyright holder for this preprint (which was not certified by peer review) is the author/funder, who has granted bioRxiv a license to display the preprint in perpetuity. It is made available under aCC-BY 4.0 International license.

[36] Annette M Hynes, Kirsten L Rhodes, and Brian J Binder. Assessing cell cycle-based methods of measuring Prochlorococcus division rates using an individual-based model. Limnology and Oceanography: Methods, 13(11):640-650, 2015.

[37] Jorge Frias-Lopez, Anne Thompson, Jacob Waldbauer, and Sallie W Chisholm. Use of stable isotope-labelled cells to identify active grazers of picocyanobacteria in ocean surface waters. Environmental Microbiology, 11(2):512-525, 2009.

[38] David A Caron. Acknowledging and incorporating mixed nutrition into aquatic protistan ecology, finally. Environmental Microbiology Reports, 9(1):41-43, 2017.

[39] Brian J Binder and Michele D DuRand. Diel cycles in surface waters of the equatorial Pacific. Deep Sea Research Part II: Topical Studies in Oceanography, 49(13-14):2601-2617, 2002.

[40] Paul M Berube, Anna Rasmussen, Rogier Braakman, Ramunas Stepanauskas, and Sallie W Chisholm. Emergence of trait variability through the lens of nitrogen assimilation in Prochlorococcus. Elife, 8:e41043, 2019.

[41] Ryan N Gutenkunst, Joshua J Waterfall, Fergal P Casey, Kevin S Brown, Christopher R Myers, and James P Sethna. Universally sloppy parameter sensitivities in systems biology models. PLOS Computational Biology, 3(10):e189, 2007.

[42] Qian Li, Kyle F Edwards, Christopher R Schvarcz, Karen E Selph, and Grieg F Steward. Plasticity in the grazing ecophysiology of Florenciella (Dichtyochophyceae), a mixotrophic nanoflagellate that consumes Prochlorococcus and other bacteria. Limnology and Oceanography, 2020.

[43] Tammi L Richardson and George A Jackson. Small phytoplankton and carbon export from the surface ocean. Science, 315(5813):838-840, 2007.

[44] Lionel Guidi, Samuel Chaffron, Lucie Bittner, Damien Eveillard, Abdelhalim Larhlimi, Simon Roux, Youssef Darzi, Stéphane Audic, Léo Berline, Jennifer R Brum, et al. Plankton networks driving carbon export in the oligotrophic ocean. Nature, 532(7600):465, 2016.

[45] Matthew B Sullivan, Joshua S Weitz, and Steven Wilhelm. Viral ecology comes of age. Environmental Microbiology Reports, 9(1):33-35, 2017.

[46] Zhao Zhao, Michael Gonsior, Philippe Schmitt-Kopplin, Yuanchao Zhan, Rui Zhang, Nianzhi Jiao, and Feng Chen. Microbial transformation of virus-induced dissolved organic matter from picocyanobacteria: coupling of bacterial diversity and DOM chemodiversity. The ISME Journal, 13(10):2551-2565, 2019.

[47] Xilin Xiao, Weidong Guo, Xiaolin Li, Chao Wang, Xiaowei Chen, Xingqin Lin, Markus G. Weinbauer, Qinglu Zeng, Nianzhi Jiao, and Rui Zhang. Viral lysis alters the optical properties and biological availability of dissolved organic matter derived from picocyanobacteria Prochlorococcus. Applied and Environmental Microbiology, 2020.

[48] Francesca Iuculano, Ignacio P Mazuecos, Isabel Reche, and Susana Agustí. Prochlorococcus as a possible source for transparent exopolymer particles (TEP). Frontiers in Microbiology, 8:709, 2017.

[49] Bianca Nahir Cruz and Susanne Neuer. Heterotrophic bacteria enhance the aggregation of the marine picocyanobacteria Prochlorococcus and Synechococcus. Frontiers in Microbiology, 10:1864, 2019 .

[50] Moira Llabrés, Susana Agustí, and Gerhard J Herndl. Diel in situ picophytoplankton cell death cycles coupled with cell division. Journal of phycology, 47(6):1247-1257, 2011.

[51] Daniella Mella-Flores, Christophe Six, Morgane Ratin, Frédéric Partensky, Christophe Boutte, Gildas Le Corguillé, Dominique Marie, Nicolas Blot, Priscillia Gourvil, Christian Kolowrat, and Laurence Garczarek. Prochlorococcus and Synechococcus have evolved different adaptive mechanisms to cope with light and UV stress. Frontiers in Microbiology, 3:285, 2012.

[52] Malgorzata Stramska and Tommy D Dickey. Short-term variability of the underwater light field in the oligotrophic ocean in response to surface waves and clouds. Deep Sea Research Part I: Oceanographic Research Papers, 45(9):1393-1410, 1998. 
bioRxiv preprint doi: https://doi org/101101/2021.06.15.448546; this version posted June 16,2021 . The copyright holder for this preprint (which was not certified by peer review) is the author/funder, who has granted bioRxiv a license to display the preprint in perpetuity. It is made available under aCC-BY 4.0 International license.

[53] David Demory, Charlotte Combe, Philipp Hartmann, Amélie Talec, Eric Pruvost, Raouf Hamouda, Fabien Souillé, Pierre-Olivier Lamare, Marie-Odile Bristeau, Jacques Sainte-Marie, et al. How do microalgae perceive light in a high-rate pond? Towards more realistic Lagrangian experiments. Royal Society open science, 5(5):180523, 2018.

[54] Gemma Kulk, Willem H van de Poll, Ronald JW Visser, and Anita GJ Buma. Low nutrient availability reduces high-irradiance-induced viability loss in oceanic phytoplankton. Limnology and Oceanography, 58(5):1747-1760, 2013.

[55] Elizabeth L Mann and Sallie W Chisholm. Iron limits the cell division rate of Prochlorococcus in the eastern equatorial Pacific. Limnology and Oceanography, 45(5):1067-1076, 2000.

[56] Elizabeth L Mann, Nathan Ahlgren, James W Moffett, and Sallie W Chisholm. Copper toxicity and cyanobacteria ecology in the Sargasso Sea. Limnology and Oceanography, 47(4):976-988, 2002.

[57] Justine Pittera, Florian Humily, Maxine Thorel, Daphné Grulois, Laurence Garczarek, and Christophe Six. Connecting thermal physiology and latitudinal niche partitioning in marine Synechococcus. The ISME Journal, 8(6):1221, 2014.

[58] Assaf Vardi, Fabio Formiggini, Raffaella Casotti, Alessandra De Martino, François Ribalet, Antonio Miralto, and Chris Bowler. A stress surveillance system based on calcium and nitric oxide in marine diatoms. PLOS Biology, 4(3):e60, 2006.

[59] Kay D Bidle. The molecular ecophysiology of programmed cell death in marine phytoplankton. Annual review of marine science, 7:341-375, 2015.

[60] Kay D Bidle. Programmed cell death in unicellular phytoplankton. Current Biology, 26(13):R594-R607, 2016.

[61] J Jeffrey Morris, Robin Kirkegaard, Martin J Szul, Zackary I Johnson, and Erik R Zinser. Facilitation of robust growth of Prochlorococcus colonies and dilute liquid cultures by helper heterotrophic bacteria. Applied and Environmental Microbiology, 74(14):4530-4534, 2008.

[62] J Jeffrey Morris, Zackary I Johnson, Martin J Szul, Martin Keller, and Erik R Zinser. Dependence of the cyanobacterium Prochlorococcus on hydrogen peroxide scavenging microbes for growth at the ocean's surface. PLOS ONE, 6(2):e16805, 2011.

[63] Daniel Fucich and Feng Chen. Presence of toxin-antitoxin systems in picocyanobacteria and their ecological implications. The ISME Journal, pages 1-8, 2020.

[64] Roy Z Moger-Reischer and Jay T Lennon. Microbial ageing and longevity. Nature Reviews Microbiology, 17(11):679-690, 2019.

[65] Daniel J Franklin. Explaining the causes of cell death in cyanobacteria: what role for asymmetric division? Journal of Plankton Research, 36(1):11-17, 2013.

[66] Dalit Roth-Rosenberg, Dikla Aharonovich, Tal Luzzatto-Knaan, Angela Vogts, Luca Zoccarato, Falk Eigemann, Noam Nago, Hans-Peter Grossart, Maren Voss, and Daniel Sher. Prochlorococcus cells rely on microbial interactions rather than on chlorotic resting stages to survive long-term nutrient starvation. mBio, 11(4), 2020.

[67] Sean Michael Kearney, Elaina Thomas, Allison Coe, and Sallie W Chisholm. Microbial diversity of co-occurring heterotrophs in cultures of marine picocyanobacteria. Environmental Microbiome, $16: 1,2021$.

[68] Lisa R Moore and Sallie W Chisholm. Photophysiology of the marine cyanobacterium Prochlorococcus: ecotypic differences among cultured isolates. Limnology and Oceanography, 44(3):628-638, 1999.

[69] Adam C Martiny, Maureen L Coleman, and Sallie W Chisholm. Phosphate acquisition genes in Prochlorococcus ecotypes: evidence for genome-wide adaptation. Proceedings of the National Academy of Sciences, 103(33):12552-12557, 2006. 
bioRxiv preprint doi: https://doi org/10.1101/2021.06.15.448546; this version posted June 16, 2021. The copyright holder for this preprint (which was not certified by peer review) is the author/funder, who has granted bioRxiv a license to display the preprint in perpetuity. It is made available under aCC-BY 4.0 International license.

[70] Andrew C Tolonen, John Aach, Debbie Lindell, Zackary I Johnson, Trent Rector, Robert Steen, George M Church, and Sallie W Chisholm. Global gene expression of Prochlorococcus ecotypes in response to changes in nitrogen availability. Molecular systems biology, 2(1):53, 2006.

[71] Zackary I Johnson, Erik R Zinser, Allison Coe, Nathan P McNulty, E Malcolm S Woodward, and Sallie W Chisholm. Niche partitioning among Prochlorococcus ecotypes along ocean-scale environmental gradients. Science, 311(5768):1737-1740, 2006.

[72] Erik R Zinser, Zackary I Johnson, Allison Coe, Erdem Karaca, Daniele Veneziano, and Sallie W Chisholm. Influence of light and temperature on Prochlorococcus ecotype distributions in the Atlantic Ocean. Limnology and Oceanography, 52(5):2205-2220, 2007.

[73] Anne W Thompson, Katherine Huang, Mak A Saito, and Sallie W Chisholm. Transcriptome response of high-and low-light-adapted Prochlorococcus strains to changing iron availability. The ISME Journal, 5(10):1580-1594, 2011.

[74] Jennifer R Brum, James Jeffrey Morris, Moira Décima, and Michael R Stukel. Mortality in the oceans: causes and consequences. Association for the Sciences of Limnology and Oceanography, pages 16-48, 2014.

[75] Anabella Aguilera, Marina Klemencic, Daniela J Sueldo, Piotr Rzymski, Leda Giannuzzi, and Maria Victoria Martin. Cell death in Cyanobacteria: current understanding and recommendations for a consensus on its nomenclature. Frontiers in Microbiology, 12, 2021.

[76] Kimberlee Thamatrakoln, David Talmy, Liti Haramaty, Christopher Maniscalco, Jason R Latham, Ben Knowles, Frank Natale, Marco JL Coolen, Michael J Follows, and Kay D Bidle. Light regulation of coccolithophore host-virus interactions. New Phytologist, 221:1289-1302, 2018.

[77] Steven W Wilhelm and Curtis A Suttle. Viruses and nutrient cycles in the sea: viruses play critical roles in the structure and function of aquatic food webs. Bioscience, 49(10):781-788, 1999.

[78] Jed A Fuhrman. Marine viruses and their biogeochemical and ecological effects. Nature, 399(6736):541-548, 1999 .

[79] Markus G Weinbauer. Ecology of prokaryotic viruses. FEMS Microbiology Reviews, 28(2):127-181, 2004.

[80] Stephen Beckett, David Demory, Ashley Coenen, John Casey, Mathilde Dugenne, Christopher Follett, Paige Connell, Michael Carlson, Sarah Hu, Samuel Wilson, Daniel Muratore, Rogelio Rodriguez-Gonzalez, Shengyun Peng, Kevin Becker, Daniel Mende, E Virginia Armbrust, David Caron, Debbie Lindell, Michael Follows, Angelique White, François Ribalet, and Joshua Weitz. Code for: Diel population dynamics and mortality of Prochlorococcus in the North Pacific Subtropical Gyre. Zenodo, doi: 10.5281/zenodo.4917227, 2021.

[81] Francois Ribalet, Chris Berthiaume, Annette Hynes, Swalwell Jarred, Michael Carlson, Sophie Clayton, Gwenn Hennon, Camille Poirier, Eric Shimabukuro, Angelicque White, and E Virginia Armbrust. SeaFlow data v1: High-resolution abundance, size and biomass of small phytoplankton in the North Pacific. Zenodo, doi: 10.5281/zenodo.3445407, June 2019.

[82] Francois Ribalet, Chris Berthiaume, Annette Hynes, Swalwell Jarred, Michael Carlson, Sophie Clayton, Gwenn Hennon, Camille Poirier, Eric Shimabukuro, Angelicque White, and E Virginia Armbrust. SeaFlow data v1, high-resolution abundance, size and biomass of small phytoplankton in the North Pacific. Scientific Data, 6(277):1-8, 2019.

[83] Mohammad Dehghani Ashkezari, Norland Raphael Hagen, Michael Denholtz, Andrew Neang, Tansy Clay Burns, Rhonda Lynn Morales, Charlotte Lee, Christopher Hill, and E Virginia Armbrust. Simons Collaborative Marine Atlas Project (Simons CMAP): an open-source portal to share, visualize and analyze ocean data. bioRxiv, 2021.

[84] Nava Baran, Svetlana Goldin, Ilia Maidanik, and Debbie Lindell. Quantification of diverse virus populations in the environment using the polony method. Nature Microbiology, 3(1):62, 2018.

[85] Svetlana Goldin, Yotam Hulata, Nava Baran, and Debbie Lindell. Quantification of T4-like and T7like cyanophages using the polony method show they are significant members of the virioplankton in the photic zone of the North Pacific Subtropical Gyre. Frontiers in Microbiology, 11:1210, 2020. 
bioRxiv preprint doi: https://doi org/101101/2021.06.15.448546; this version posted June 16,2021 . The copyright holder for this preprint (which was not certified by peer review) is the author/funder, who has granted bioRxiv a license to display the preprint in perpetuity. It is made available under aCC-BY 4.0 International license.

[86] Evelyn B Sherr, David A Caron, and Barry F Sherr. Staining of heterotrophic protists for visualization via epifluorescence microscopy. Lewis Publishers, Boca Raton, 1993.

[87] M Heldal, DJ Scanlan, S Norland, F Thingstad, and NH Mann. Elemental composition of single cells of various strains of marine Prochlorococcus and Synechococcus using X-ray microanalysis. Limnology and Oceanography, 48(5):1732-1743, 2003.

[88] Johann S Lopez, Nathan S Garcia, David Talmy, and Adam C Martiny. Diel variability in the elemental composition of the marine cyanobacterium Synechococcus. Journal of Plankton Research, 38(4):1052-1061, 2016.

[89] Christopher P Kempes, Stephanie Dutkiewicz, and Michael J Follows. Growth, metabolic partitioning, and the size of microorganisms. Proceedings of the National Academy of Sciences, 109(2):495-500, 2012.

[90] Richard J Puxty, Andrew D Millard, David J Evans, and David J Scanlan. Viruses inhibit $\mathrm{CO}_{2}$ fixation in the most abundant phototrophs on earth. Current Biology, 26(12):1585-1589, 2016.

[91] Howard C Berg and Edward M Purcell. Physics of chemoreception. Biophysical Journal, 20(2):193-219, 1977.

[92] Alexander G Murray and George A Jackson. Viral dynamics: a model of the effects of size, shape, motion and abundance of single-celled planktonic organisms and other particles. Marine Ecology Progress Series, pages 103-116, 1992.

[93] M Von Smoluchowski. Investigation of a mathematical theory on the coagulation of colloidal suspensions. Z. Physik. Chem.(Ger.), 92:155, 1917.

[94] Kazuyoshi Murata, Qinfen Zhang, Jesús Gerardo Galaz-Montoya, Caroline Fu, Maureen L Coleman, Marcia S Osburne, Michael F Schmid, Matthew B Sullivan, Sallie W Chisholm, and Wah Chiu. Visualizing adsorption of cyanophage P-SSP7 onto marine Prochlorococcus. Scientific Reports, $7: 44176,2017$.

[95] Albert Einstein. Über die von der molekularkinetischen theorie der wärme geforderte bewegung von in ruhenden flüssigkeiten suspendierten teilchen. Annalen der physik, 322(8):549-560, 1905.

[96] Katya Frois-Moniz. Host/virus interactions in the marine cyanobacterium Prochlorococcus. PhD thesis, Massachusetts Institute of Technology, 2014.

[97] Shay Kirzner, Efrat Barak, and Debbie Lindell. Variability in progeny production and virulence of cyanophages determined at the single-cell level. Environmental Microbiology Reports, 8(5):605-613, 2016.

[98] Svetlana Fridman, José Flores-Uribe, Shirley Larom, Onit Alalouf, Oded Liran, Iftach Yacoby, Faris Salama, Benjamin Bailleul, Fabrice Rappaport, Tamar Ziv, et al. A myovirus encoding both photosystem I and II proteins enhances cyclic electron flow in infected Prochlorococcus cells. Nature Microbiology, 2(10):1350, 2017.

[99] Raphaël Laurenceau, Nicolas Raho, Mathieu Forget, Aldo Arellano, and Sallie W Chisholm. Frequency of mispackaging of Prochlorococcus dna by cyanophage. The ISME Journal, 2020.

[100] Steven J Biller, Paul M Berube, Debbie Lindell, and Sallie W Chisholm. Prochlorococcus: the structure and function of collective diversity. Nature Reviews Microbiology, 13(1):13, 2015.

[101] Jonathan P Zehr, Joshua S Weitz, and Ian Joint. How microbes survive in the open ocean. Science, 357(6352):646-647, 2017.

[102] Thomas Kiørboe. How zooplankton feed: mechanisms, traits and trade-offs. Biological Reviews, 86(2):311-339, 2011.

[103] Thomas Kiørboe. A mechanistic approach to plankton ecology. Princeton University Press, 2008.

[104] Susanne Menden-Deuer and Evelyn J Lessard. Carbon to volume relationships for dinoflagellates, diatoms, and other protist plankton. Limnology and Oceanography, 45(3):569-579, 2000. 
bioRxiv preprint doi: https://doi org/10.1101/2021.06.15.448546; this version posted June 16,2021 . The copyright holder for this preprint (which was not certified by peer review) is the author/funder, who has granted bioRxiv a license to display the preprint in perpetuity. It is made available under aCC-BY 4.0 International license.

[105] Lawrence F Shampine and Mark W Reichelt. The MATLAB ODE Suite. SIAM Journal on Scientific Computing, 18(1):1-22, 1997.

[106] Pierre Marrec, Gérald Grégori, Andrea M Doglioli, Mathilde Dugenne, Alice Della Penna, Nagib Bhairy, Thierry Cariou, Sandra Hélias Nunige, Soumaya Lahbib, Gilles Rougier, et al. Coupling physics and biogeochemistry thanks to high-resolution observations of the phytoplankton community structure in the northwestern Mediterranean Sea. Biogeosciences, 15(5):1579, 2018.

[107] John R Casey, Karin M Björkman, Sara Ferrón, and David M Karl. Size dependence of metabolism within marine picoplankton populations. Limnology and Oceanography, 64:1819-1827, 2019.

[108] Welkin H Pope, Peter R Weigele, Juan Chang, Marisa L Pedulla, Michael E Ford, Jennifer M Houtz, Wen Jiang, Wah Chiu, Graham F Hatfull, Roger W Hendrix, et al. Genome sequence, structural proteins, and capsid organization of the cyanophage Syn5: a horned bacteriophage of marine Synechococcus. Journal of Molecular Biology, 368(4):966-981, 2007.

[109] Naama P Dekel-Bird, Sarit Avrani, Gazalah Sabehi, Irina Pekarsky, Marcia F Marston, Shay Kirzner, and Debbie Lindell. Diversity and evolutionary relationships of T7-like podoviruses infecting marine cyanobacteria. Environmental Microbiology, 15(5):1476-1491, 2013.

[110] David M. Karl and Matthew J. Church. Microbial oceanography and the Hawaii Ocean Time-series programme. Nature Reviews Microbiology, 12:699-713, 2014.

[111] Michael D McKay, Richard J Beckman, and William J Conover. Comparison of three methods for selecting values of input variables in the analysis of output from a computer code. Technometrics, $21(2): 239-245,1979$.

[112] Heikki Haario, Marko Laine, Antonietta Mira, and Eero Saksman. DRAM: efficient adaptive MCMC. Statistics and Computing, 16(4):339-354, 2006.

[113] Peter G Verity, Diane K Stoecker, Michael E Sieracki, and James R Nelson. Grazing, growth and mortality of microzooplankton during the 1989 North Atlantic spring bloom at 47 N, 18 W. Deep Sea Research Part I: Oceanographic Research Papers, 40(9):1793-1814, 1993.

[114] Susanne Neuer and Timothy J Cowles. Protist herbivory in the Oregon upwelling system. Marine ecology progress series. Oldendorf, 113(1):147-162, 1994.

[115] Hera Karayanni, Urania Christaki, France Van Wambeke, Melilotus Thyssen, and Michel Denis. Heterotrophic nanoflagellate and ciliate bacterivorous activity and growth in the northeast Atlantic Ocean: a seasonal mesoscale study. Aquatic Microbial Ecology, 51(2):169-181, 2008.

\section{Materials and Methods}

\section{Model availability}

Both the ECLIP and the ECLIPSS models are coded in MATLAB. Core code for running model simulations, analysis and plotting is archived on Zenodo ([80]).

\section{Empirical data}

We use data collected from the HOE-Legacy 2A cruise in Summer 2015. In all Figures, the 12 days shown represent the time between 06:00:00 24th July 2015 and 06:00:00 August 5th 2015 local time.

- SeaFlow measurements of Prochlorococcus cell abundance, size-structure and carbon biomass:

The SeaFlow continuously measures forward scattering, red and orange fluorescence intensities of particles ranging in size from $\sim 0.4$ to $4 \mu \mathrm{m}$ in diameter from underway samples every 3 minutes. A combination of manual gating and statistical methods was used to identify Prochlorococcus based on forward scatter (457/50 bandpass filter), red fluorescence (572/28 bandpass filter) and orange fluorescence (692/40 band-pass filter) relative to $1-\mu \mathrm{m}$ calibration beads (Invitrogen F8823). Cell diameter of individual cells was estimated from SeaFlow-based light scatter by the application of Mie light scatter theory to a simplified optical model, using an index of refraction of 1.38 [81, 82]. Data was obtained via Simons CMAP [83]. 
- Virus abundance and infection:

Samples for virus abundance and infection were collected every 4 hours at $15 \mathrm{~m}$ depth using a CTDrosette equipped with $12 \mathrm{~L}$ niskin bottles [20]. Samples for cyanophage abundances (40 mL) were filtered through a $0.2 \mu \mathrm{m}$ syringe top filter, flash frozen, and stored at $-80^{\circ} \mathrm{C}$. Samples for infected cells $(40 \mathrm{~mL})$ were filtered through a $20 \mu \mathrm{m}$ nylon mesh, fixed with electron microscopy grade glutaraldehyde $\left(0.125 \%\right.$ final abundance), incubated for 30 minutes in the dark at $4^{\circ} \mathrm{C}$, flash frozen, and stored at $-80^{\circ} \mathrm{C}$. Cyanophage abundances were analysed using the polony method for T7-like [84] or T4-like [85] cyanophage families. Virally infected Prochlorococcus was quantified using the iPolony method [20] in which Prochlorococcus cells were sorted with a BD Influx cytometer and screened for intracellular T4-like and T7-like cyanophage DNA.

- Measurements of heterotrophic nanoflagellates:

Samples for nanoplankton (protists 2-20 $\mu \mathrm{m}$ in diameter) abundances were collected every 4 hours at $15 \mathrm{~m}$ depth [21]. Preserved samples were stored at $4^{\circ} \mathrm{C}$. Slides were prepared from preserved samples within 12 hours of sampling by filtering $100 \mathrm{~mL}$ subsamples down to $1 \mathrm{~mL}$ onto blackened $2 \mu \mathrm{m}, 25 \mathrm{~mm}$ polycarbonate filters and staining the samples with $50 \mu \mathrm{L}$ of a 4'-6'diamidino-2pheylindole (DAPI, Sigma-Aldrich, St. Louis, MO) working solution $\left(1 \mathrm{mg} \mathrm{mL}^{-1}\right)$ for 5-10 minutes in the dark [86]. Stained samples were filtered and rinsed; filters were placed on glass slides with a drop of immersion oil and coverslip, then sealed with clear nail polish. Slides were stored at $-20^{\circ} \mathrm{C}$ until analysis. Heterotrophic nanoplankton abundances were counted using epifluorescence microscopy from triplicate slides, and differentiated from photo/mixotrophic nanoplankton by the lack of chlorophyll a autofluorescence in plastidic structures when viewed under blue-light excitation $[21]$. 